\title{
The Digitalization of Street Art and Graffiti: Analysis on Ladies On Wall's Social Media Account
}

\author{
R. Handaru Pratama ${ }^{1}$, Lita Sari Barus ${ }^{2}$, Renny Nurhasana ${ }^{3}$ \\ $\left\{{ }^{1}\right.$ radenhandaru18@gmail.com, ${ }^{2}$ lita_barus@yahoo.com, ${ }^{3}$ rennynurhasana@ui.ac.id $\}$ \\ ${ }^{1,2,3}$ School of Strategic and Global Studies, Universitas Indonesia, Indonesia
}

\begin{abstract}
Female street artist and graffiti writers in Indonesia are incorporated in the Ladies on Wall, which was formed as a room for the female street artist and graffiti writer in producing works. Formerly, street art and graffiti were considered as male activities due to the construction of male's masculinity. In addition, street art and graffiti are categorized as a temporary art works due to the weather, overwritten works, as well as the government policies that prohibit the existence of the art works. The aim of this article is to analyze the use of media by the Ladies on Wall community as a form of digitizing works to show their existence. The netnography method is used in this article, by making the Instagram account of the Ladies on Wall Community as the subject of the research. The results of this research indicate the ability of Ladies on Wall Instagram account as a room to appreciate, preserve, develop a discussion spaces, legitimize and bring up the women's perspective in street art and graffiti world.
\end{abstract}

Keywords: street art, graffiti, ladies on wall, Instagram

\section{INTRODUCTION}

The city facilitates the street artist and graffiti writer to exhibit their artworks in any available city spaces. In this case, the artists have specific purposes ranging from the medium of self-expressions, issues cultivation, also as a part of the city's revitalization program. Due to its placement in the public space, urban spaces artworks are known as a public art, where specifically designed to be displayed in a public spaces, including the street art and graffiti. Street art and graffiti are well developed in cities in Indonesia, from independence time, the New Order era yet to the digital era with the complex form of street art and graffiti. In fact, the progress of the street art and graffiti in Indonesia are difficult to be tracked due to the lack of records and documentation.

The previous several studies discussed street art and graffiti in many different points of view. Some examines from urban study exhibit that street art and graffiti existence, give a both positive and negative impact to the city. Street art and graffiti play a role in city revitalization programs and represents the city commercial value and its identity (Look up to Mulcahcy \& Flessas, 2015; Manrique, 2015; Landy \& Steele, 1967; Ursic, 2014). On the other hand, several studies examines vandalism show irregularities which led to some criminal activities which implements to the implementation of preventive policies through the street art and graffiti in several cities (Look up to Vanderveen \& Van Eijk, 2015 ; Stewart, 2008; 
Douglas, 2014). In addition, some literature discusses the gender perspective of the women's role in the world that considered as a masculine activity (Look up to Macdonald, 2001; Gentry, 2008; Perrin, 2015; Monto, Machalek, \& Anderson, 2012). Meanwhile, another type of research attempts the social media development's influence correlation on street art and graffiti (Look up to MacDowall \& de Souza, 2018). None of the several existing studies discussed the use of social media as an existence and preservation medium by the female street art and graffiti writers community.

In Indonesia, Ladies on Wall formed in 2014 as a room for female street artist and graffiti writers. Firstly known as an annual drawing event, Ladies on Wall evolved as a community. As time goes by, the number of participants of the annual event were increased significantly. These indications was influenced by media coverage of the activities and existence of the community (Look up to Agnes, 2016; Anonymous, 2018; Firdausiah, 2017). Moreover, the community once invited by the Australian Embassy in Jakarta collaborated with Australian street artist to created art works in Brisbane, Australia.

This article will discuss the use of social media, Instagram, by this community which is considered to have an important role for the development of the community, the face of female street artists and the graffiti writers itself as well as efforts to preserve their works. This is considered important considering that street art and graffiti have generally undergone a digitization process. In analyzing the discussion in this article, the author uses the netnographic method which will focus on Instagram accounts of the Ladies on Wall community. Through this account, Ladies on Wall documents and distributes their works digitally. Author will make observations starting from the beginning of The development of Ladies on Wall's Instagram account - beginning of launch to date. In addition, the author will also conduct interviews with the founders of Ladies on Wall to get in-depth information regarding this community.

\section{METHODOLOGY}

The author uses a qualitative approach to the netnographic method in explaining the topic of this article. Netnography is a naturalistic research technique that uses information that is publicly available in online forums (Kozinet, 2010). The method of netnography combines different methods in a single approach that focuses on the study of communities and cultures on the internet (Baym, 1995). The author uses the netnographic method to analyze deeply the Ladies on Wall community as a community of female street artists and graffiti writers who attempts to digitize their works through their Instagram account. That way, their existence as a female street artists and graffiti writers can be known and maintained by society.

The stage of research carried out on netnographic methods are similar with the traditional ethnographic methods. It starts with determining the boundaries and research questions, choosing an online community, conducting participatory observation, also data analysis and interpretation. In addition, as in ethnography, the method of netnography is naturalistic, immersive, descriptive, intuitive, adaptive to the objective context.

\section{ANALYSIS}

\subsection{Cities and Art: Street Art and Graffiti}

Before deep diving into street art and graffiti as part of urban art, firstly we need to understand the basic concept that acts as umbrella for each of the different arts. One of it is 
public art - art that is specifically designed and displayed through public space and is accessible by all (Jones, 1992; Goldstein, 2005; Knight, 2008).

Historically, any form of public art has decorated the city around the West. Starting from graffiti in caves up to cities in the Roman - whereby draped with carvings, decoration, ornaments as seen in archeologic sites in Pompeii and Ercolano (Quintavall, 2007). Additionally, ornaments and colors have also been seen in churches and iconic buildings in Europe during the Middle Age. The Middle Age is an era where art became more visual, however the Enlightenment Era is a period where art begun to enter public space. (Visconti, Sherry Jr, Borghini, \& Anderson, 2010, p. 513)

Compared to previous historical period, whereby art became an elite domain and how monuments or architectural icons enter public space to stress on the sacred places, the concept of public art have long developed post World War II (Ursic, 2014). Public art transformed into a mediator between artist and commoners who tries to express their concerns on social issues through their art works. The development of contemproary art that are situated in cities like xxx, government buildings, parks, schools, hospitals, railway stations and shopping malls have increased in the late 1960s (Miles, 1997, p. 3). Through his piece called Art in a City in the year 1967, John Willet indicated that art in public space could give a positive impact to the city - wherein the usage of public art emerged (Willet, 2007).

Apart from public art, another used concept on art in public space is urban art. Different from public art, urban art specifically talks about street art and graffiti in streets and other legal public spaces (Blanche, 2015). Other than that, unlike public art, urban art can be found in museums or galleries - and also sold commercially. Urban art is usually created by street artist to earn their living.

Moreover, graffiti is defined as art in the form of writing - could be an identity of the writer, individual or in groups - that are found in public space, done illegally using spray paint or marker. Tagging is an example of graffiti (see Figure 1), a signature doodle that is drawn artistically, and made to highlight the writer's existence and showing ownership of a certain area (Bowen, 1999; Bates, 2014). People who creates graffiti is better known as graffiti writer and usually done in big groups or also known as crew. In this case, a graffiti writer's identity is the core of graffiti, not the message underneath. As part of art, graffiti has its own set of rules and codes which becomes the "rules of the game" that needs to be obeyed by all graffiti writers (Curwen \& MacGillivray, 2007). With this mechanism, graffiti is usually valued as a subculture with its personal way of working and may not be understood by all. As time goes by, graffiti itself have grown to be more artistic (see Figure 2), which is being inspired by the hiphop culture.

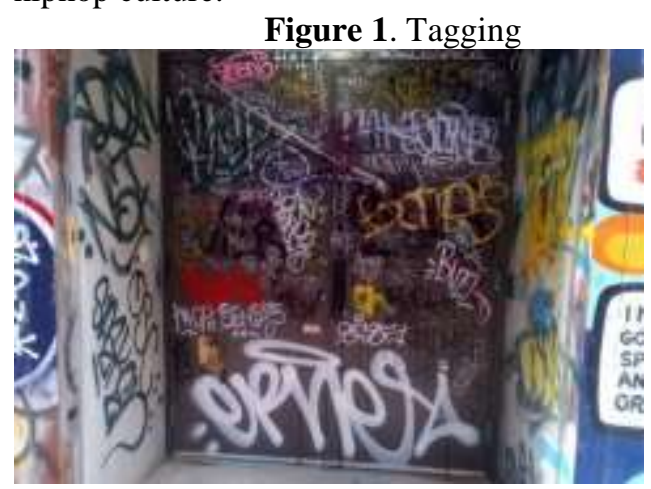

Figure 2. Piece

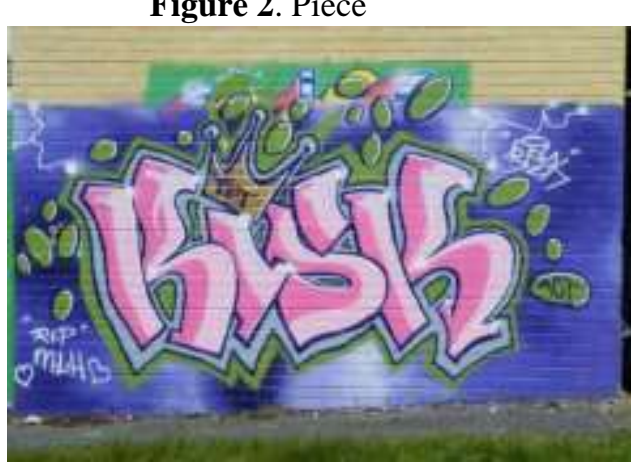

source: Widewalls.ch 
Meanwhile, street art means all forms of artistic expression that uses public space as its "canvas" - a direct derivative of graffiti - in the form of two or three dimensions, a term coined by Allan Schwartzman in 1985 (Lewisohn, 2008). Street art is also known as post-graffiti, because it uses media and techniques that were not used during the graffiti movement in the 1970s and 1980s in New York (Bou, 2005). Some forms of street art includes murals, stencil, wheat paste, slaps-sticker street art, street installations, flash mobs, projection mapping. Unlike graffiti which is dominated by writings, street art is more dominated with images so that it is easier to understand by those who studies or sees it. In addition, street art is more flexible than graffiti that is bound to certain rules of the game and can use other materials besides spray paint and markers. However, what both of them have in common is that it is done illegally and not for commercial purposes. Both are also participatory arts because every street artist and graffiti writer can override, destroy, even add additional work on top of what have been made by others. In addition, street art and graffiti are temporary art - could be damaged by the weather, government policies that prohibit its existence, and also overwritten by other people's work (Blanché, 2015).

In connection with its illegal existence, every government in the whole world have different policies in response to the emergence of street art and graffiti in public spaces. Many local governments consider street art and graffiti as a form of crime and vandalism. This is based on broken windows theory, which assumes that if a small form of crime is not prevented or acted upon it will generate even more similar behavior and even greater forms of crime (Wagers, Sousa, \& Kelling, 2008). Therefore, many local governments are trying to prevent and remove street art and graffiti. Several cities in Australia, the Netherlands, the United Kingdom and the United States of America imposed a preventive policy on the existence of street art and graffiti by taking measures to prevent and eliminate the acts of vandalism (Vanderveen \& Van Eijk, 2015).

On the other hand, several cities in the world have "friendly" policies for street artists and graffiti writers, and even the city government uses street art and graffiti to beautify city spaces and attract tourists (see also Koster \& Randall, 2005; McAuliffe, 2012 ; Zukin \& Braslow, 2011). For example, in New York in 1985, the Arts for Transit Office was formed to initiate programs that place permanent and temporary art, in which they work with professional artists, the arts community, and cultural institutions, in the New York subway station (Feuer, 1989, p 141) In addition, at the end of 2017 the Jakarta city government collaborated with students, paint companies and banks, to make murals on non-toll flyover poles at Kasablanka area, with the aim of creating a space for cultural expression (Erwanti, 2017). Here, street art and graffiti can play a role in realizing urban regeneration carried out by the city government in urban spaces that are considered necessary for renewal, and this effort can also be in line with the process of commodification of space. Even so, when street and graffiti art has been legally carried out and financed by certain sponsors, it is considered only to be urban art.

In addition to its attachment to public and urban spaces, another interesting issue to be discussed in street art and graffiti is the view on assessing how street art and graffiti is gender biased and is merely a male activity. This is based on a comparison of the number of male and female artists who are present in the world of street art. When referring to the literature discussing street art and graffiti artists in the world, such as Nicholas Ganz's work entitled Graffiti World: Street Art from Five Continents, there are only 11 female artists from a total of 144 artists discussed in the book (Ganz, 2004). While in the work of Rafael Schacter and John Fekner titled World Atlas Street Art and Graffiti, there are only 3 female artists out of a total of 97 artists in the work (Schacter \& Fekner, 2013). On the other hand, stereotypes of ordinary 
people also still see street art and graffiti as activities carried out by men, even in works that are considered "neutral" (Parisi, 2015).

The dominance of men in the world of street art and graffiti is also highly related to the reasons underlying men interested in carrying out these activities. One of them is street art and graffiti facilitating men in constructing and strengthening their masculinity identity (Macdonald, 2001, p. 96). This is inseparable from illegal factors in street art and graffiti so that it is considered a form of crime, as well as factors in the use of locations on the streets that are considered dangerous and high risk. Here, male artists gain their desire to construct their respective masculinity identities, but on the other hand women are not interested in that, so it is not surprising that the number of women in the world of street art is less than that of men.

Although considered a minority in the world of street art, the existence of female artists still has a role in the world of street art and graffiti. One example is the street art and graffiti women's group, Harimi, in Egypt which emerged as a form of political representation that demands a change in the role of women in society (De Ruiter, 2015). They use street art and graffiti as a medium to campaign for their message regarding gender equality. In addition, as an effort to realize women's participation in public space, it is important for them to claim urban spaces through their work.

\subsection{Women, Street Art, and Graffiti in Indonesia: Ladies on Wall}

Basically, the development of street art and graffiti in Indonesia is difficult to trace its journey. Besides being not a form of local cultural art, lack of documentation and archiving is also a factor that causes this situation. However, street art and graffiti became one of the mass communication media as well as propaganda tools for the freedom fighters. This can be seen from the big writing that reads Freedom is the Glory of Any Nation. INDONESIA for INDONESIANS! taken around 1945 by photographer Cas Oorthuys.

Figure 3. Freedom is the Glory of Any Nation. INDONESIA for INDONESIANS!

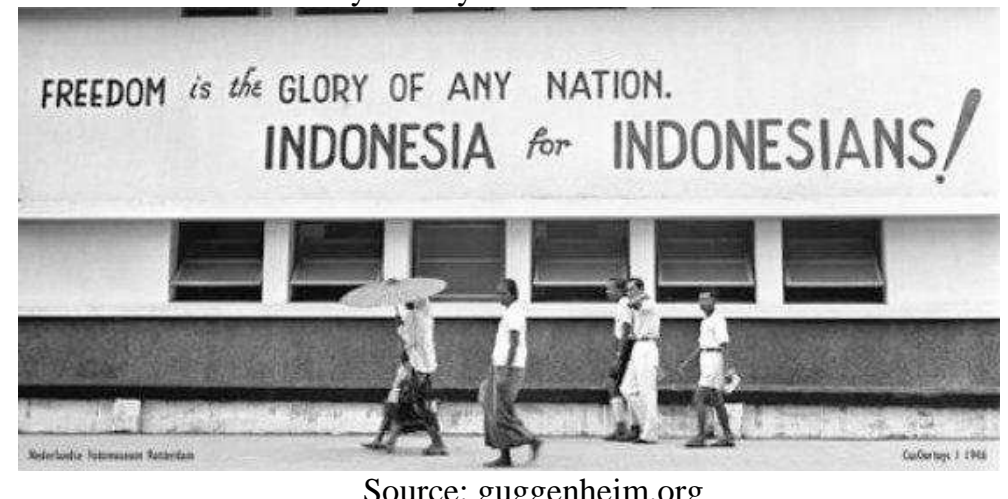

Meanwhile, in the world of urban architecture, street art in the form of murals is used by YB Mangunwidjaja in the slum revitalization program on the outskirts of Code River, Yogyakarta with the aim of changing the appearance of slums so that they are more scenic when viewed. Through the revitalization program of the city kampong, Mangunwidjaja received the Aga Khan awards in 1992 (Network, 2018). 
Then in 1998, during the New Order era, student actions were marked by the use of street art as their medium of expression. For example, in Yogyakarta there is the Taring Padi Group which creates murals that demand the fall of President Soeharto from his power at that time (Bartolomeus, 2013). Only in early 2000, when information was open and technology developed, street artists and graffiti writers began to be able to access information from the internet, which had an impact on the transformation of street art and graffiti in Indonesia. Graffiti art which was originally only in the form of tagging began to lead to more artistic forms of graffiti with various forms (bubble, wild style and 3D). This was spearheaded by fine arts students in Jakarta, Bandung and Yogyakarta who were inspired by various graffiti writers worldwide (Wicandra, 2006).

Meanwhile in Indonesia, the existence of female street artists and graffiti writer are members of a community called Ladies on Wall. This community was formed with the aim of being a place for female street artists and graffiti writer to gather and get to know each other. This is motivated by the difficulties experienced by female street artists and graffiti writers in finding female partners when they want to make street art and graffiti. At first, Ladies on Wall was not intended to be a community, but only an annual event attended by female street artists and graffiti writer from several cities in Indonesia. In the event they did a "drawing" activity together in a predetermined place.

Ladies on Wall was first held in 2014 in Jakarta, with 8 female artists (see figure 4). Due to the enthusiasm of the participants, the Ladies on Wall program continued to be held in the following years and the number of participating participants increased. In 2015 in Bogor, the number of participants participated as many as 18 people, while in 2016 in Tangerang the number of participants increased to 32 people. At the last, in 2017 in Bandung, the number of participants increased to 60 people. With more and more female street artists and graffiti writers appearing, they are organizing themselves into a community.

Figure 4. Female Street Artists and Graffiti Writers in Ladies on Wall 2014

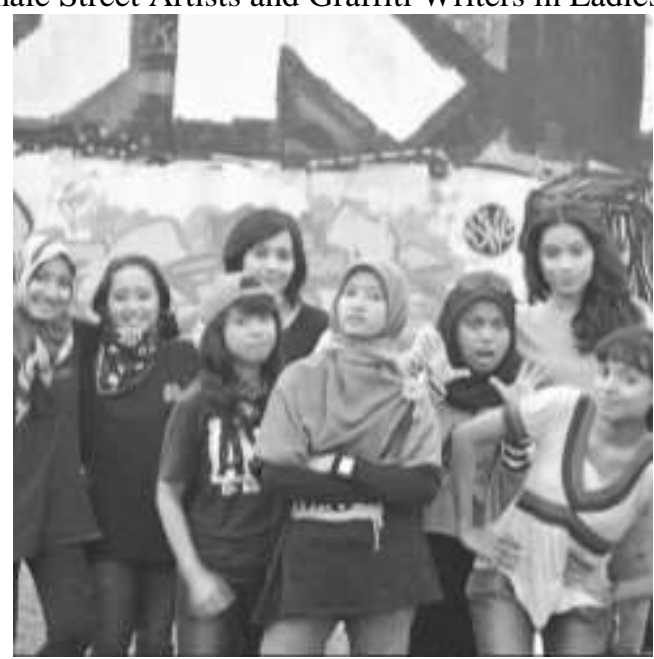

Source: Instagram, Ladies on Wall 


\subsection{Street Art and Graffiti Digitalization}

As a dynamic art, street art and graffiti encounter a transformation with the development of digital technology, both in terms of the form of work and the behavior of street artists themselves. Especially with the presence of web 2.0 and social media platforms (MacDowall L., 2008). Information disclosure makes the preference of street artists and graffiti writers more widespread, causing the work they produce more complex. In addition, through digital technology, a street artist and graffiti writer has the potential to get a wider audience, not only the people who passing around their work.

One of the social media platforms that facilitates street artists and graffiti writers in developing and conducting preservation of their works is Instagram. Previously, Instagram was first launched in 2010, and at that time it could only be used by Apple's iPhone users. In 2012, Android Mobile App users began to be able to use the Instagram application and not long after that Facebook acquired Instagram with a value of US \$ 715 million (Luckerson, 2016). Instagram active users also continue to increase since this application is acquired by Facebook. Initially, 30 million active users of Instagram each day, then by the end of 2017 Instagram's active users per day increased to 500 million users (Arnold, 2017).

Basically, Instagram is a social media platform, used by people to share photos and videos. On Instagram, each user can personalize their Instagram profile which functions as a personal photo folder. Besides being able to upload photos and videos, Instagram application users can also use the filter feature to beautify their photos and videos. In addition, Instagram users can also add other information which includes the place where the photo or video was taken, a brief description of the photo or video and provide a specific theme by adding a hashtag.

Instagram application is not only famous for the general public, but also among street artists and graffiti writers. Due to the fact that the Instagram application is made "friendly" for mobile phone users, street artists and graffiti writers use this application to document and distribute their work to the community, and interact directly with the observers (MacDowall \& de Souza, 2018). In addition, street artists and graffiti writers able to elevate the process of making up to the publication of their work on the streets in real time, so that their audience can experience the work online. As a digital object, street art and graffiti will last longer and have a wider range of observers than just being art on the street. Social media, in this case Instagram, provides alternative solutions to the nature of temporary street art and graffiti.

With some of the considerations above, many street artists and graffiti writers have social media accounts, especially Instagram, as a way to digitize their work. As well as the Ladies on Wall, who have tried to document their works and distribute them to the public through Instagram from the beginning. Until now, their Instagram account followers have reached 11.6 thousand people.

\section{FINDINGS}

Since the first time Ladies on Wall held an event in 2014 to September 2018, Ladies on Wall's Instagram account has posted 986 times and followed by 11,607 followers. In the 986 posts, the content presented was in the form of photos (957) and videos (29). Based on the analysis of the photos or video contents that was posted, there were five categories of content found which are information related to the events they participated in or was held, media coverage of them on a community or individual basis, women's "drawing" activities, street art and graffiti they produce both individually and in groups and several other contents. It is 
found that $41 \%$ of their total Instagram account posts are works that they have produced both individually or in groups. This is in line with the purpose of this community, which is to become a space for female street artists and graffiti writers to work. Furthermore, by digitizing works of street artists and graffiti writers, Ladies on Wall seeks to always preserve the work.

On the other hand, Ladies on Wall also strives to appreciate those who have made art works. In each post, Ladies on Wall lists who made the art work, so that the observer would know who the artist are. Ladies on Wall's Instagram account often re-posts the art work or activities related to street art uploads of street artists and female graffiti writer in their respective accounts. The use of \#repost has become the most frequent used hashtag in Ladies on Wall 's Instagram account. The effort to digitize through Instagram allows these artists to be known personally by their observers. Because basically, when their work is only on the road, observers do not have complete information on who made the art work itself.

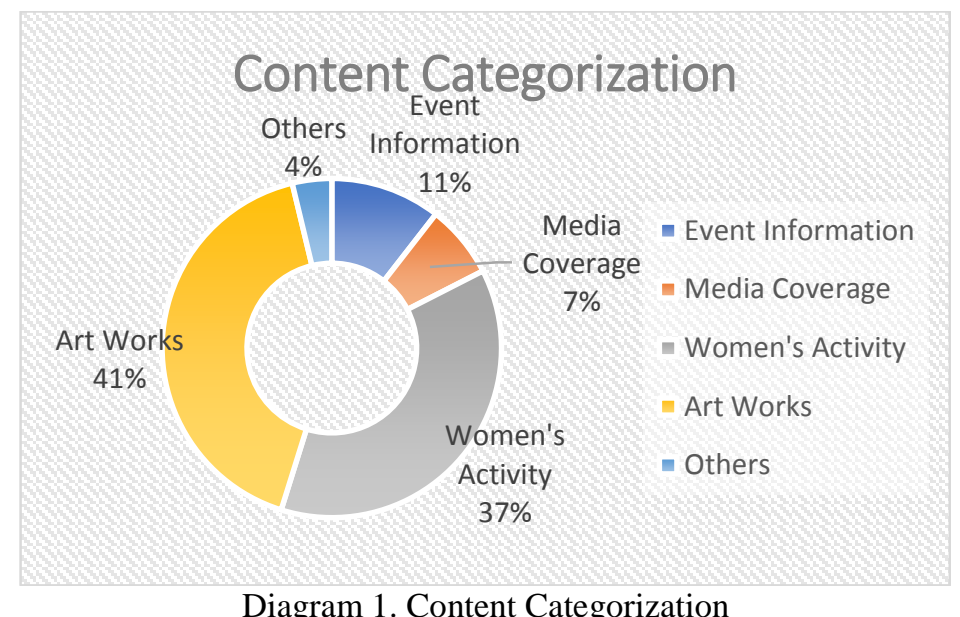

Another interesting find was that $37 \%$ of the total posts showed the activities of women who were "drawing". From this data, Ladies on Wall emphasizes the narrative of women in the world of street art and graffiti which are considered as male activities, where stereotypes in society is still present (Parisi, 2015) In addition, women's role will indeed be more "striking" when Ladies on Wall features photos of women who were drawing, because basically it is difficult for people to identify women's rol in street art and graffiti. Moreover, it can also be seen that women who carry out street art and graffiti activities are very diverse, which shows that women with any background can become part of the world of street art and graffiti. This negates the dominant discourse that street art and graffiti are masculine domains that assume women do not have the ability to survive the demands of this activity (Macdonald, 2001). It is precisely women who are challenged to learn or do street art and graffiti because it is not common for all women to do such activity (Bunga, interview results, April 23, 2017)

Ladies on Wall's Instagram account also posts news that covers their activities. This is what the author considers as recognition and legitimacy of the mainstream media relating to what they do. This legitimacy is important considering that street art and graffiti are still considered masculine realms and there is gender bias (Gentry, 2008) In addition, Instagram infrastructure makes street art and graffiti more participatory. This is indicated by the features of likes and the comments column in every post, which in Ladies on Wall's case, is used as a medium of interaction between artists, showing appreciation from observers of the works and 
achievements of artists, showing people's interest in joining Ladies on Wall, and people used to introduce Ladies on Wall to women who are interested in street art and graffiti. Here, with the comment column, Instagram creates a discussion space between artists and observers which is not found on the road, because observers find it difficult to interact directly with artists (MacDowall \& de Souza, 2018).

Also, another thing that needs to be discussed is the 'caption' feature that works as an additional description of the uploaded photos or videos. With this feature, street artists and graffiti writers can provide brief explanations regarding the meaning of their art work, the events they run, and showcase their attention to women related issues. This certainly makes it easier for observers to understand the meaning of the work of artists and writers, as well as works in museums and galleries that have a short description column in the corner of their works.

\section{CONCLUSION}

Street art and graffiti have become part of urban life from the past and have developed in terms of the methods, forms and media used. This phenomenon is influenced by the presence of web 2.0 and social media, which are used by street artists and graffiti writers to document the work and activities. As a part of digital art, street art and graffiti have a longer life and are consumed by higher number of people than objects on the streets

This article shows that the digitalization of street art and graffiti also supports the existence of the female street and graffiti art community, Ladies on Wall. Through Instagram accounts, Ladies on Wall provides valuable information related to events they follow or organize, media coverage from them in the community or individuals, women's drawing activities, street art and graffiti they produce both individually or in groups. Socialized through Instagram, Ladies on Wall is able to be a room for female street artists and graffiti, to appreciate and preserve their works, develop a discussion spaces, legitimize and articulate women's narratives in the street art and graffiti world.

\section{ACKNOWLEDGEMENT}

This research based on grant scheme of PITTA (Publikasi International Terindeks untuk Tugas Akhir) 2018 or also known as Indexed International Publications for Final Projects toward Universitas Indonesia students.

\section{REFERENCE}

[1]. Quintavalle, A. C. (2007, June 22). Graffiti, un'arte da non relegare in museo. Corriere della Sera, p. 55.

[2]. Visconti, L. M., Sherry Jr, J. F., Borghini, S., \& Anderson, L. (2010, Oktober). Street Art, Sweet Art? Reclaiming the "Public" in Public Place. Journal of Consumer Research, Inc, 37.

[3]. Ursic, M. (2014). 'City as a work of art' - Influence of public art in the city. Ljubljana: University of Ljubljana.

[4]. Miles, M. (1997). Art, Space and the City: Public Art and Urban Futures. London: Routledge.

[5]. Willet, J. (2007). Art in a City. Liverpool: Liverpool University Press. 
[6]. Feuer, W. (1989). Public Art from a Public Sector Perspective. Ann Arbor: UMI Research Press.

[7]. Erwanti, M. O. (2017, December 1). Anies-Sandi Resmikan Program Mural Tiang JLNT di Kasablanka. Retrieved from detikNews: https://news.detik.com/berita/3751112/anies-sandi-resmikan-program-mural-tiang-jlntdi-kasablanka

[8]. Derwanz, H. (2013). Street Artists. Careers on the Art and Design Markets. Bielefeld: Transcript.

[9]. Blanché, U. (2015). Street Art and related terms - discussion and working definition. Street Art \& Urban Creativity Scientific Journal, 34.

[10]. Wagers, M., Sousa, W., \& Kelling, G. (2008). Broken Windows. In W. R., \& M. L., Environmental Criminology and Crime Analysis (pp. 247-262). Cullompton: Willan.

[11]. Vanderveen, G., \& Van Eijk, G. (2015). Criminal but Beautiful: A Study on Graffiti and the Role of Value Judgments and Context in Perceiving Disorder. European Journal on Criminal Policy and Research.

[12]. Ganz, N. (2004). Graffiti World. Street Art from the Five Continents. New York: Harry N. Abrams.

[13]. Schacter, R., \& Fekner, J. (2013). The World Atlas of Street Art and Graffiti . New Haven: Yale University Press.

[14]. Parisi, V. (2015). The Sex of Graffiti. Urban Art, Women and "Gender Perception": testing biases in the eye of the observer. Street Art \& Urban Creativity Scientific Journal, 1, 53-62.

[15]. Macdonald, N. (2001). The Graffiti Subculture Youth, Masculinity and Identity in London and New York. New York: Palgrave Macmillan.

[16]. De Ruiter, A. (2015). Imaging Egypt's political transition in (post-) revolutionary street art: on the interrelations between social media and graffiti as media of communication. Media, Culture \& Society, 582-601.

[17]. Wicandra, O. B. (2006). Graffiti di Indonesia: Sebuah Politik Identitas Ataukah Tren? (Kajian Politik Identitas pada Bomber di Surabaya). Nirmana, 51-57.

[18]. Network, A. K. (2018, August 3). Kampung Kali Cho-de. Retrieved from akdn.org: https://www.akdn.org/architecture/project/kampung-kali-cho-de

[19]. Bartolomeus, L. (2013, January 16). Street Art dan Kehidupan Sosial Politik Indonesia. Retrieved from Guggenheim.org: https://www.guggenheim.org/id/blogs/map/street-artdan-kehidupan-sosial-politik-indonesia

[20]. MacDowall, L. (2008). The Graffiti Archive and the Digital CIty. In D. Butt, J. Bywater, \& N. Paul, Place: Local Knowledge and New Media Practice (pp. 134-147). Newcastle: Cambridge Scholars Publishing.

[21]. Luckerson, V. (2016, April 19). Here's Proof That Instagram Was One of the Smartest Acquisitions Ever. Retrieved from Time.com: http://time.com/4299297/instagramfacebook-revenue/

[22]. Arnold, J. (2017, December 26). Which Was The Better Acquisition For Facebook: WhatsApp Or Instagram? Retrieved from Forbes.com: https://www.forbes.com/sites/quora/2017/12/26/which-was-the-better-acquisition-forfacebook-whatsapp-or-instagram/\#3222e0577a4e

[23]. MacDowall, L. J., \& de Souza, P. (2018). 'I'd Double Tap That!!': street art, graffiti, and Instagram research. Media, Culture and Society, 3-22.

[24]. Jones, S. (1992). Art in Public: What, Why and How. Sunderland: Artic Producers Publishing. 
[25]. Goldstein, B. (2005). Public Art by the Book. Seattle: University of Washington Press.

[26]. Knight, C. K. (2008). Public Art: Theory, Practice and Populism. Malden: Blackwell Publishing.

[27]. Koster, R., \& Randall, J. E. (2005). Indicators of Community Economic Development Through Mural-Based Tourism. Canadian Geographer-Geographe Canadien, 42-60.

[28]. McAuliffe, C. (2012). Graffiti or Street Art? Negotiating the Moral Geographies of the Creative City. Journal of Urban Affairs, 189-206.

[29]. Zukin, S., \& Braslow, L. (2011). The Life Cycle of New York's Creative Districts: Reflections on the Unanticipated Consequences of Unplanned Cultural Zones. City, Culture and Society, 131-140.

[30]. Mulcahcy, L., \& Flessas, T. (2015). Limiting Law: Art in the Street and Street in the Art. Law Culture and Humanities.

[31]. Manrique, D. F. (2015, January 13). Local Street Art and Graffiti Curricular Design. Boston, Massachusetts, USA: Boston University.

[32]. Landy, E. E., \& Steele, J. M. (1967). Graffiti As A Function of Building Utilization. Perceptual and Motor Skills, 711-712.

[33]. Stewart, J. (2008). Graffiti Vandalism? Street Art and The City: Some Considerations. UNESCO Observatory, Faculty of Architecture, Building and Planning, The University of Melbourne.

[34]. Douglas, L. (2014, May). Street Art in London Breaking Windows or Displacing Populations. Indiana, Indiana, USA: Indiana University Bloomington.

[35]. Gentry, E. (2008, May). Girls' Night Out: Female Graffiti Artists in Gendered City. Bowling Green, Ohio, USA: Bowling Green State University.

[36]. Perrin, S. (2015, December 2). Re-Defining Revolution: A Case Study of Women and Graffiti in Egypt. Burnaby, Canada: Simon Fraser University.

[37]. Monto, M. A., Machalek, J., \& Anderson, T. L. (2012). Boys Doing Art: The Construction of Outlaw Masculinity in a Portland, Oregon, Graffiti Crew. Journal of Contemporary Ethnography, 259-290.

[38]. Agnes, T. (2016, May 11). Ladies on Wall, Komunitas Grafiti Perempuan Pertama di Indonesia. Retrieved from detik.com : https://hot.detik.com/spotlight/3207716/ladieson-wall-komunitas-grafiti-perempuan-pertama-di-indonesia

[39]. Anonymous. (2018, May 7). Ladies on Wall. Retrieved from thejakartapost.com: http://www.thejakartapost.com/multimedia/2018/05/07/ladies-on-wall.html

[40]. Firdausiah, Z. (2017, February 22). Ladies On Wall, Komunitasnya Bomber Wanita Indonesia. Retrieved from Muslimahdaily.com: http://muslimahdaily.com/muslimahzone/community/item/956-ladies-on-wall-komunitasnya-bomber-wanitaindonesia.html

[41]. Kozinet, R. V. (2010). Netnography: Doing Ethnographic Research Online. London: SAGE Publications Ltd.

[42]. Baym, N. K. (1995). The Emergence of Community in Computer-Mediated Communications. Thousand Oaks: SAGE Publications Inc.

[43]. Bowen, T. (1999). Graffiti Art: A contemporary study of Toronto. Studies in Art Education: A Journal of Issues and Research, 22-39.

[44]. Bates, L. (2014). Bombing, Tagging, Writing: An Analysis of The Significance of Graffiti and Street Art. Philadelphia, Pennsylvania, USA: University of Pennsylvania.

[45]. Curwen, M. S., \& MacGillivray, L. (2007). Tagging as a Social Literacy Practice. Journal of Adolescent \& Adult Literacy, 354-369.

[46]. Lewisohn, C. (2008). Street Art: The Graffiti Revolution. New York: Abrams. 
[47]. Bou, L. (2005). Street Art: The Spray Files. New York: Collins Design. 